\title{
Project-based Learning: "Teens' Magazine"- A Case Study in an English Language Classroom in Albania
}

\author{
Merita Hoxha, PhD Candidate
}

Mentor teacher at "Naim Frashëri" school, University "Aleksandër Xhuvani" Email: hoxha.merita@yahoo.com

\author{
Doi:10.5901/ajis.2016.v5n3p73
}

\section{Abstract}

Over the past 5 years, Project-Based Learning (PBL) has become an integral part of the curriculum in all elementary and high schools in Albania. This might be due to the fact that this is an alternative way of teaching which tries to engage all the students in the learning process despite their level of knowledge in a specific subject. PBL is a method of teaching and learning which puts the students at the center of the learning process and as a result of students having to produce a final result, it considered to be very motivating and satisfactory for them. Scholars think that PBL integrates knowing and doing and is therefore a style of active learning. Generally, it involves real life topics which students have to discuss in groups, research and even generate solutions. This increases the possibility of long-term retention of skills and concepts. In this case study we will see how a mini version of PBL operates. The project "Teens' magazine" was conducted with students of the 7th grade in "Naim Frashëri" school, in Elbasan, Albania. I will give details on how the project took place, the process of creating the groups, assigning the tasks and how it was assessed. Another important part of this case study is describing what worked and what didn't work during the project. Because this project was conducted for three years with 7th graders, this case study will also give information on how parts of the process have changed and improved.

Keywords: project-based learning, student, teacher, group, assessment

\section{Rationale}

During the past 20 years many things have changed in the education system in Albania. As in many other countries, our classes used to be teacher-centered, while based on new pedagogical theory, we are trying to modernize current methodology. Changes are not easy and they happen gradually. Moving from small, isolated projects to PBL is one of the key challenges within our education system. Since 2014, with the reformation of the education system and changes in the curricula, teachers have been asked to focus more on PBL, unfortunately often without proper training or appropriate instruction in how to apply PBL.

\section{Literature Review}

PBL started to be used as an alternative teaching method in the last two decades but it is becoming very popular among teachers, students and schools in many parts of the world. Despite this it is important to emphasize that the roots of PBL date back nearly 100 years ago to the famous American scholar John Dewey, who believed that engaging students in solving real problems during learning will develop their personal investment. The main reason for the growing popularity of PBL is that it is considered to be a student-centered approach which combines knowledge and skills. Some other reasons for using PBL are:

- PBL makes school more engaging for students.

- PBL improves learning

- PBL builds success skills for college, career, and life

- PBL provides opportunities for students to use technology

- PBL makes teaching more enjoyable and rewarding

- PBL connects students and schools with communities and the real world

Because it is a new approach, it is important to understand what is and what is not PBL. Lenz (2016) says that currently, there is no widely agreed-upon definition and detailed description of what high quality PBL looks like in practice. Sometimes "hands-on" learning and "fun" activities are mistaken as PBL, says the author. Even Thom (2011) draws 
attention to the fact that sometimes people get confused and find it hard to make the difference between "doing projects" and PBL, stressing that PBL is a far more evolved method of instruction. The author believes that moving from "doing projects" to PBL has many advantages for the students as it integrates knowing and doing, it focusses on assessment which incorporates formative feedback, detailed rubrics, and multiple evaluations of content and skills and finally PBL offers to students a real life experience. In order to be successful, Thom (2011) presents 7 core principles of PBL:

1. Identify the Challenge

2. Craft the Driving Question

3. Build the Assessment

4. Plan Backwards

5. Enroll and Engage

6. Facilitate the Teams

7. Keep the End in Mind

Despite this the author says that PBL is still a work in progress, but is worth applying.

Project-based learning is a form of situated learning and it is based on the constructivist finding that students gain a deeper understanding of material when they actively construct their understanding by working with and using ideas say Krajcik and Blumenfeld (2006).

Many other scholars emphasize that using PBL has many advantages for the students, mostly because it is a student-centered approach. According to Mosier, Bradley-Levine and Perkins (2015) there are many benefits of PBL which have to do with $21^{\text {st }}$ century skills such as improving critical thinking, collaboration, problem solving, presenting, engagement and motivation. On the other hand, Gültekin's (2006) researches point out that PBL strengthens selfconfidence of students and helps them to carry out responsibility.

\section{Methodology}

This case study will show how a mini-version of PBL was applied in an English Language classroom in "Naim Frasheri" school in Albania. Seven classes participated for three years. All the students were $7^{\text {th }}$ graders; 169 students in total. The project lasted 3 months and it was called "Teens' magazine".

\subsection{The driving question}

The driving question was "What do Albanian teens like?" Although this is not the kind of question that encourages deep critical thinking, it was chosen because the project was in English and it is difficult for many students to reach such a level of thinking. Another reason for choosing such a question was the teacher's desire to elicit full participation from all students. To answer this question, the students had to work in groups. Mostly they worked in groups of 5-6 students and the members had to choose a leader, assign tasks, set deadlines, etc.

\subsection{Choosing the topic}

When choosing the topic "Teens' magazine" the teacher considered some elements as crucial for its success. The topic had to be something:

- Close to their age

- Similar with their interest

- Encouraging interaction

- For students of all levels

- Easily found information

- That COULD be done

The teacher presented the rubrics of the magazine and all the groups had to incorporate them into their own magazine. There were seven rubrics in total:

1. Curiosities

2. Science and environment

3. Problem page

4. Interviewing a famous person

5. Show biz 


\section{Sports}

7. Culture corner

All the students were advised to refer to the sources of information and were taught how to reference the sources.

\subsection{How were the groups created}

During the first class of the project the students were divided into groups. The teacher decided who would go into which group. This was done for three main reasons. The first reason had to do with the idea that PBL is a way to teach students real-life skills. Considering that in real life you are not able to choose your coworkers, but have to collaborate with everyone in the work place, the groups were created based on this principle. Second, it is often observed that students tend to stay and work with only a few friends, not wanting to cooperate with some other students or even to talk to them. Being in the same group with students they do not have a strong friendship, and having the same goal, might help all the students to get to know each other better. Third, in this way the teacher could create groups with students of different levels of knowledge. Considering that all the groups had the same task; creating a teens' magazine, it would be difficult if lower-level students were left to work alone.

\subsection{How the groups worked}

Once the groups were created, the students' first task was to choose a leader. The role of the leader was to keep records of the work of each group member and he/she was also responsible for the management of the group work, time and materials. The groups could cooperate with each other in every moment but once in three weeks the groups had to report to the teacher how the project was going. In these meetings, the students and the teacher discussed and shared ideas about their work and progress

\subsection{A work in progress}

As the project lasted three months it was necessary to have frequent meetings with the students to discuss about it. These meetings were officially held once in two weeks. During the meetings students shared ideas with other members of the group and with the teachers.

\subsection{Introducing the magazine}

This step of the project was closely related to the group assessment part. Each group had three minutes to present its magazine to the other groups and say a few words about it. The presentation was done in the presence of the English teacher, IT teachers and Art teachers, as these subjects were closely related to the creation of the magazine. These teachers also helped students prepare the magazine by advising them.

\subsection{Assessment}

As Thom (2011) says, assessment is one of the 7 principles of PBL. It is very important for the students to get not just summative assessment but even formative assessment. For this reason, the assessment of the product of PBL was focused on these issues:

1. The group completed a self-assessment sheet

At the last stage of the project each group was required to complete a self-assessment sheet. The sheet had two sectors: a) the individual assessment sector; in which each member of the group assessed himself/herself and b) the group assessment sector; in which all the group members assessed the work they had done.

2. The groups assessed each-other

This part of the assessment was conducted during the final stage of the project. This stage, was conceived as both a presentation and an assessment stage. Each group presented the final product of the project and assessed other groups' magazines giving them a mark from 5-10. The students had to write in an assessment sheet the marks for the other groups and also:

- Two things they liked about other magazines

- Two things they did not like 
This was done in order for the groups to justify the marks given. The chart below describes how the group assessment was done:

As we can see Group 1 assessed Group 2, 3, 4 and 5. In the same way other groups assessed each other.

\title{
4. The Teacher Assessed Each Group
}

After self-assessment and group assessment the teacher assessed every magazine. The assessment was focused mostly on these topics: a) did the students cover all the rubrics? b) was their work original? c) did the students meet the deadline? and also some aspects of language learning.

It is important to say that the self-assessment sheet was only presented during the third year of the project. Vavla (2013: 40) emphasizes the importance of self-assessment by saying that it helps students to create a clear frame of themselves through critical thinking. Encouraging objective self-assessment is very important as often students tend to underestimate or overestimate themselves. Self-assessment and peer assessment are two new approaches in our country. Generally, it is the teacher the one who assesses and often his/her assessment is taken for granted. Teaching students to assess themselves objectively, identify and accept their strength and weaknesses is a stepping stone towards improving themselves.

\subsection{What worked}

All the students participated actively. This was one of the greatest success of the project. As one the aims of applying $\mathrm{PBL}$ is to encourage students to become active learners, we can say that through this project this aim was almost achieved. The report of the leaders of each group underlined that all the students had prepared something for the magazine. Here we are not talking about quality of the work done, because it depends a lot on students' level of English, but about the fact that every student participated actively as part of a team.

\subsection{What did not work}

There were two issues that did not meet minimum standards during the project. The first one was plagiarism. Although all the students were strongly advised to reference sources, in $36 \%$ of the cases this standard was not met. The second was procrastination. Because students had to do projects in multiple other subjects, sometimes they did not meet the deadline. This unfortunately affected the project as not all the groups could present the magazine and the presentation was delayed.

\section{Conclusion}

\author{
"Tell me, and I will forget \\ Show me, and I will remember \\ Involve me, and I will understand". \\ Chinese Proverb
}

Maybe this old Chinese proverb is the future of the teaching and learning process. PBL is not just an alternative way of teaching and learning, it is becoming a necessity in preparing future citizens to be able to face the real world. This case study showed that even though there are still many things that need to improve, it accomplished one of the most important goals of PBL, which is making all students active learners and motivating them as much as possible.

\section{References}

Gültekin M (2006). Opinions on Students' Early Childhood Education Program about Project-Based Learning. Eskişehir Osmangazi University J. Soc. Sci. 7(2):19-45

Krajcik. J \& Blumenfeld. P (2006) Project-Based Learning. The Cambridge Handbook of the Learning Sciences. R. Keith Sawyer (ed). Cambridge University Press

Larmer. J \& Mergendoller. J (2010). Seven Essentials for Project-Based Learning. Educational leadership. Vol 68. No 1

Mosier. G, Bradley-Levine. J and Perkins. T (2015). Students' perceptions of project-based learning within the new tech school model. International Journal of Educational Reform. 25.1

Thom. M (2011). Project Based Learning A Bridge Just Far Enough. Teacher Librarian 39.2 38-42 
Vavla, L. (2013). Vlerësimi dhe procesi i testimit në metodologjinë e sotme të mësimit të gjuhëve të huaja. UT, Tiranë, Shqipëri http://www.bie.org/blog/a_way_to_ensure_high_quality_project_based_learning_for_all http://www.bie.org/about/why_pbl http://www.edutopia.org/project-learning http://www.pbl-online.org/mod1/movies/msatmovie.htm http://pbl-online.org/ 
